\title{
Morphology of seeds and seedlings, and substrates in germination of Citrus limetta
}

\author{
Angelita Lorrayne Soares Lima Ragagnin ${ }^{1 *}$ (i) Cláudia Dayane Marques Rodrigues ${ }^{1}$ (D) \\ Gabriel Silva Costa ${ }^{1}$ (D) Givanildo Zildo da Silva ${ }^{2}$ (i) Carla Gomes Machado $^{2}$ (i) \\ Simério Carlos da Silva $\mathrm{Cruz}^{3}$ (D) Danielle Fabíola Pereira da Silva ${ }^{1}$ (D)
}

${ }^{1}$ Grupo de Fruticultura, Universidade Federal de Jataí (UFJ), 75801-615, Jataí, GO, Brasil. E-mail: angelitaragagnin@gmail.com. ${ }^{*}$ Corresponding author.

${ }^{2}$ Laboratório de Sementes, Universidade Federal de Jataí (UFJ), Jataí, GO, Brasil.

${ }^{3}$ Departamento de Solos, Universidade Federal de Jataí (UFJ), Jataí, GO, Brasil.

ABSTRACT: This research studied the morphology of seeds and seedlings, in addition to obtaining information about the type and time of germination of sweet lemon seeds in five substrates (on blotting paper, between blotting paper, on washed sterilized sand, between washed sterilized sand and in paper roll). C. limetta seeds were measured, and external description was performed. Afterwards, sown in the sand and kept at $25{ }^{\circ} \mathrm{C}$ to monitoring germination and morphological description of the resulting seedlings. A second experiment was evaluated for substrate efficiency: paper roll, on and between paper, on and between sand in the germination of C. limetta seeds. Speed index, average time and relative frequency of germination were evaluated. In addition, date of the first and last germination count was established. Treatment averages were compared using the Tukey test at 5\% probability. C. limetta seeds are ovoid, slightly wrinkled and polyembryonic. Germination is hypogeal, cryptocotylar or phanerocotylar. The seedlings have leathery eophylls with simple leaves, elliptical shape or close to the elliptical, tending to ovate. It has a pivoting root system that is colored yellow to cream with the presence of secondary roots. The average germination time is between 18 and 22 days. The substrate indicated for seed germination is on paper.

Key words: sweet lemon, hypogeal germination, polyembryonic, reproduction.

Morfologia de sementes, plântulas e substratos na germinação de Citrus limetta

RESUMO: Objetivou-se com o presente trabalho estudar a morfologia de sementes e plântulas, além de se obter informações sobre o tipo e tempo da germinação das sementes de limão-doce em cinco substratos (em papel mata-borrão, entre papel mata-borrão, em areia esterilizada lavada, entre areia esterilizada lavada e em rolo de papel). Sementes de C. limetta foram mensuradas suas dimensões e realizada a descrição externa. Posteriomente, semeadas entre areia e mantidas à $25^{\circ} \mathrm{C}$ para acompanhamento da germinação e descrição morfologica das plântulas resultantes. Um segundo experimento foi avaliado quanto a eficiência dos substratos: rolo de papel, sobre e entre papel, sobre e entre areia na germinação de sementes de C. limetta. Foram avaliados o índice de velocidade, o tempo médio e a frequência relativa da germinação. Além disso, foi estabelecida a data da primeira e última contagem da germinação. As médias dos tratamentos foram comparadas pelo teste de Tukey a 5\% de probabilidade. As sementes de C. limetta são ovoides, levemente enrugadas e poliembrionicas. A germinação é hipógea, criptocotiledonar ou fanerocotiledonar. As plântulas apresentam eofilos coriáceos com folhas simples, formato eliptico ou próximo do elíptico, tendendo para ovado. Apresenta sistema radicular pivotante coloração de amarelo a creme com presença de raizes secundárias. O tempo médio de germinação é entre 18 e 22 dias. O substrato indicado para germinação das sementes é sobre papel.

Palavras-chave: limão-doce, germinação hipógea, poliembrionia, reprodução.

\section{INTRODUCTION}

Citrus species are cultures of great socioeconomic importance for the country, mainly due to exportation of juice and labor employed in its production (STRUIVING et al., 2013). Citrus limetta, commonly known as sweet lemon, is native to South and Southeast Asia and cultivated in the Mediterranean basin (HASHEMI et al., 2017; SHAKOOR \& NASA, 2016).
This plant has as main product the fresh fruit that is used for juice. The juice has chemical properties, such as antioxidant activity, as well as antibacterial properties, and can be used as a functional food (HASHEMI et al., 2017; SHAKOOR \& NASA, 2016). Hesperidin, eriocitrin and diosmin are the main flavonoids of sweet lemon (OUSSALAH et al., 2006; HASHEMI et al., 2017). The essential oil of sweet lemon peel contains limonene (49.24\%) and $\gamma$-terpinene (12.14\%) and has an antibacterial effect 
against Pseudomonas putida in the conservation of meat (OUSSALAH et al., 2006; COLECIO-JUÁREZ et al., 2012).

The study of seed morphology can be useful in germination test in judgment and classification of normal and abnormal seedlings, as well as in identification of the types of abnormalities present (SILVA et al., 2019; SOUZA et al., 2020). In citrus, this study can differentiate species with a large number of seeds and those with high nucellar polyembryony, which are desirable for choice of rootstock (GUERRA et al., 2012). However, given this importance, few studies focus on study of the germination morphology of the Citrus genus.

Given the importance of basic studies in the field of seed production and technology, the determination of suitable substrates is essential for evaluating germination of a species, however it is not found for Citrus spp. recommendation of these in the Rules for Seed Analysis - RSA (BRASIL, 2009). Thus, this research evaluated the morphology of seeds and seedlings, in addition to obtaining information about germination of Citrus limetta seeds in different substrates.

\section{MATERIALS AND METHODS}

In an orchard of adult plants from sexually propagated around six years of age, fruits of Citrus limetta (sweet lemon) were harvested from nine plants and in each plant five fruits were harvested in September 2019 in the city of Porto Nacional - TO and transported in Nylon bags in a non-refrigerated car to the Federal University of Jataí (UFJ) in Jataí, GO.

At Agronomic Research Center of UFJ, the fruits were washed, selected and the seeds were extracted. These were sent to the Seed Laboratory, at the same institution. Where they were subjected to disinfestation in 3\% sodium hypochlorite for three minutes. After this process, the fruits were characterized in terms of weight, length, diameter, hue angle of the epidermis and number of seeds per fruit, and the seeds were characterized in terms of width and length. After characterization, the seeds were subjected to two experiments in a completely randomized design.

For the first experiment, four replicates of 25 seeds were used, which were sown between washed and sterilized sand in transparent plastic boxes $(11.0 \mathrm{x}$ $11.0 \times 3.5 \mathrm{~cm})$ and kept in a germination chamber at $25^{\circ} \mathrm{C}$ to monitoring the germination of Citrus limetta seeds. For morphology, seeds were measured for length, width and thickness; in addition, their external description was carried out. In relation to seedlings at the end of germination, the description of the root (primary and secondary), collection, hypocotyl, cotyledons, epicotyl and the first pair of eophils was carried out. For this, they were performed with the aid of a binocular stereomicroscope and a digital camera.

For the second experiment, the efficiency of five substrates (on blotting paper, between blotting paper, on washed sterilized sand, between washed sterilized sand and in paper roll) was evaluated on germination of Citrus limetta seeds, using four repetitions per substrate, each repetition with 25 seeds.

The first four substrates were packed in transparent gerbox boxes. The wetting mode for paper was 2.5 times the dry mass, while for sand they were moistened to a capacity of $60 \%$ retention (BRASIL, 2009). Paper rolls and boxes with substrates and seeds were packed in low density polyethylene plastic bags and kept in a germination chamber at $25^{\circ} \mathrm{C}$.

The evaluations were carried out daily at the same time, from the beginning of emergence of seedling epicotyls in the sand until stabilization of the number of seedlings, being considered the normal and most vigorous seedling for account, when it presented more than one per seed, according with criteria described in BRASIL (2009).

Germination speed index was also evaluated using the formula described by MAGUIRE (1962) and the average time and the relative frequency of germination, using the formulas described in SANTANA \& RANAL (2004).

In addition, the date of first germination count was established based on $50 \%+1$ of the total seedlings germinated per treatment and date of the final germination count on the day after which germination stabilization occurred in three successive counts.

Data were submitted to normality and error homogeneity test, and subsequently to the F test of analysis of variance (ANOVA). Averages were compared using the Tukey test at $5 \%$ probability. The statistical program Rbio, version 119: 06/06/2019 (BHERING, 2017) was used for the analyzes.

\section{RESULTS AND DISCUSSION}

Fruits os Citrus limetta had the following characteristics: weight $325.6 \mathrm{~g} \pm 82.6$; length 84.5 $\mathrm{mm} \pm 8.9$; diameter $87.2 \mathrm{~mm} \pm 8.4$ and hue angle of color of the epidermis $92.6^{\circ} \pm 10.4$, the closer the hue angle is to $90^{\circ}$ on color scale indicates more intense yellow color (KONICA MINOLTA, 2020) and an average number of $16.5 \pm 5.5$ seeds per fruit. These characteristics are similar to that described 
by GOMES et al. (2020) in a study of the genetic diversity of this species.

Seeds of Citrus limetta have dimensions of $11.2 ; 6.4$ and $5.3 \mathrm{~mm}$ in length, width and thickness, respectively. These are ovoid, slightly wrinkled and polyembryonic (Figure 1). According to MENDONÇA et al. (2016) and SALIM et al. (2020) basic characteristics of seeds, seedlings and fruit can be useful in identifying families, genus, species or even a genotypes of a plant.

It was possible to observe the difference in coloration of cotyledons in the polyembryonic seed that originated four seedlings, two with cotyledons more greenish and the others tending to cream color. Regarding coloration, DUARTE et al. (2013) affirmed that this characteristic of seeds is the result of color combination of cotyledons, it could vary according to the quantity of embryos in the seed, representing a possible estimate of the degree of polyembryony and for the identification of the zygotic embryo.

Germination of Citrus limetta was hypogeal, while for cotyledons it was observed that, of seeds that originated only one seedling, it was cryptocotylar and when they were polyembionic seeds, they are phanerocotylar. There was also a variation in vigor between seedlings originated from these two types of seeds, when only one seedling occurs it is much more vigorous with more developed structures and presence of secondary roots. While seeds with more than one seedling there was a difference in vigor, from this seedling missing some essential structure, such as leaf primordia, until fully formed seedlings, but with less vigor when compared to those originating from a seedling per seed, in these too the development of epicotyl was observed.

FERREIRA et al. (2019) asked about the advantages of the polyembryonic seedlings of Carapa surinamensis, who concluded that there is a variation of vigor between the seedlings obtained, since they share the same reserves and compete for external factors, mainly space for the development of the root and aerial part, and light. They also pointed out that viable seedlings were obtained in all treatments, that is, the seedling vigor can be increased through its individualized maintenance.

Polyembryony is an advantage for production of rootstocks, since that higher the rate, greater the chances of obtaining clones of the parent plant, which is the objective in the commercial multiplication of rootstocks. The lower production of clones, that is, only one seedling per seed, in genetical enhancement programs, could be used as female parents in controlled hybridizations and would be advantageous, allowing greater ease in obtaining and selecting the zygotic embryos of interest (DUARTE etal., 2013). KASHYAPet al. (2018) affirmed that polyembryony varies according to the ecological region and the cultivar, suggesting that it is specific to each variety in relation to the region. They also affirmed that this does not seem to be a limiting factor in the germination capacity.

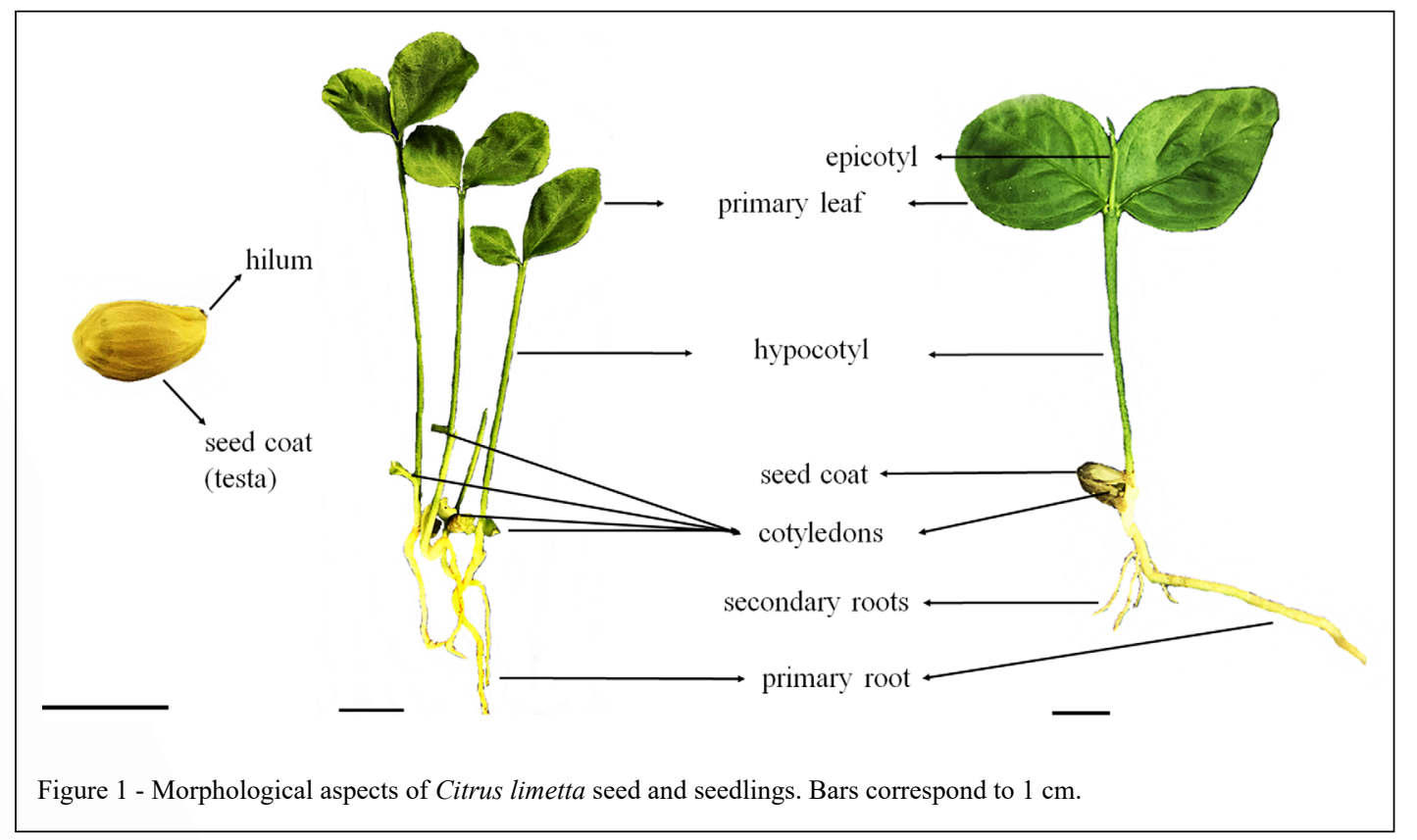

Ciência Rural, v.52, n.8, 2022. 
At 30 days after sowing, the sweet lemon seedlings presented leathery eophylls with simple leaves and the presence of a citrus fragrance, common to the genus, elliptical shape or close to the elliptical, tending to ovate, this greater variation in size and leaf shape observed in polyembryonic plants. The leaves presented margin of the crenulated type, dark green color and the pattern of peninervous venation. These leaf characteristics are befitting with that described by MAZZINI \& PIO (2010) in the morphological characterization of six citrus varieties with ornamental potential.

It has a pivoting root system with a yellow to cream color, presence of secondary roots, mainly in seedlings from seeds with less occurrence of polyembryony. Collection is cylindrical and yellowish-white; hypocotyl is cylindrical, greenish. Cotyledons are opposite and vary in color from green to cream; the epicotyl was observed only in seeds without the presence of polyembryony, being cylindrical and green. The characteristics of lemon seedlings are similar to those described by COELHO et al. (2001) for tangerine seedlings (C. reticulata).

When the substrates were evaluated for the germination of Citrus limetta (Table 1), their effects were not seen only in the average germination time, for which it was between 18 and 22 days for the germination of the seeds in the evaluated substrates.

It was reported that substrate on paper provides conditions for greater germination and in less time, due to variables of the first count and germination speed index; however, it did not differ from seeds sown between paper for these same variables (Table 1). This last substrate did not differ when seeds were placed on and between sand, and those sown in sand did not differ when they were placed to germinate on paper roll. The behavior of the three variables was similar, except for first count of seeds sown between sand; they were lower than those sown between paper.

Use of on paper is more economical when compared to between paper, so the use of the first substrate is indicated. This was also used to evaluate germination of citrus rootstock cultivars (SARMIENTO et al., 2016). The best germination performance in paper substrate can be attributed to the vegetative structure's development lower physical impairment and higher aeration of this substrate in comparison to sand (MACHADO et al., 2019). Use of sand causes difficulties in maintaining the sterile laboratory environment, in addition to difficulties in obtaining, storing, disposing and reusing it, recommendations described in the BRASIL (2009).

The use of a paper roll provided the development of fungi present in the seeds, probably internal, once they were disinfected. This fact can be justified since the paper roll, in this case, served as an incubation for incidence of these fungi. Plausible, since incubation on a paper roll is a specific method for detecting some fungi in the Manual of Sanitary Seeds Analysis (BRASIL, 2009).

In the relative frequency of Citrus limetta seed germination (Figure 2), it was reported that over time germination reaches a maximum point, declines and rises again, so the frequency polygons showed polymodal distribution, with heterogeneous germination, because they have more than two peaks, with the exception of sowing between sand that are unimodal, only one peak (SANTANA \& RANAL, 2004). It could be said that the germination in this last substrate mentioned above would have greater synchronization; however, the peak of germination

Table 1 - Germination, first count and speed index of Citrus limetta seeds in different substrates.

\begin{tabular}{lccr}
\hline Substrates & Germination (\%) & First count (\%) & Germination speed index \\
\hline On paper & $82 \mathrm{a}$ & $56 \mathrm{a}$ & $1.31 \mathrm{a}$ \\
Between paper & $67 \mathrm{ab}$ & $39 \mathrm{ab}$ & $1.00 \mathrm{ab}$ \\
On sand & $49 \mathrm{bc}$ & $20 \mathrm{bc}$ & $0.69 \mathrm{bc}$ \\
Between sand & $49 \mathrm{bc}$ & $15 \mathrm{c}$ & $0.64 \mathrm{bc}$ \\
Paper roll & $36 \mathrm{c}$ & $14 \mathrm{c}$ & $0.45 \mathrm{c}$ \\
Medium square & $5.79^{* *}$ & $11.14^{* *}$ & $0.09^{* *}$ \\
Error & 0.73 & 0.96 & 0.01 \\
CV $(\%)$ & 11.45 & 19.08 & 7.19 \\
\hline
\end{tabular}

Means followed by the same letter, in the same column, did not differ significantly by Tukey's test, at $1 \%$ probability. ${ }^{* *}:$ Significant at $1 \%$ probability; CV: Coefficient of variation. -: not submitted to statistical analysis. 

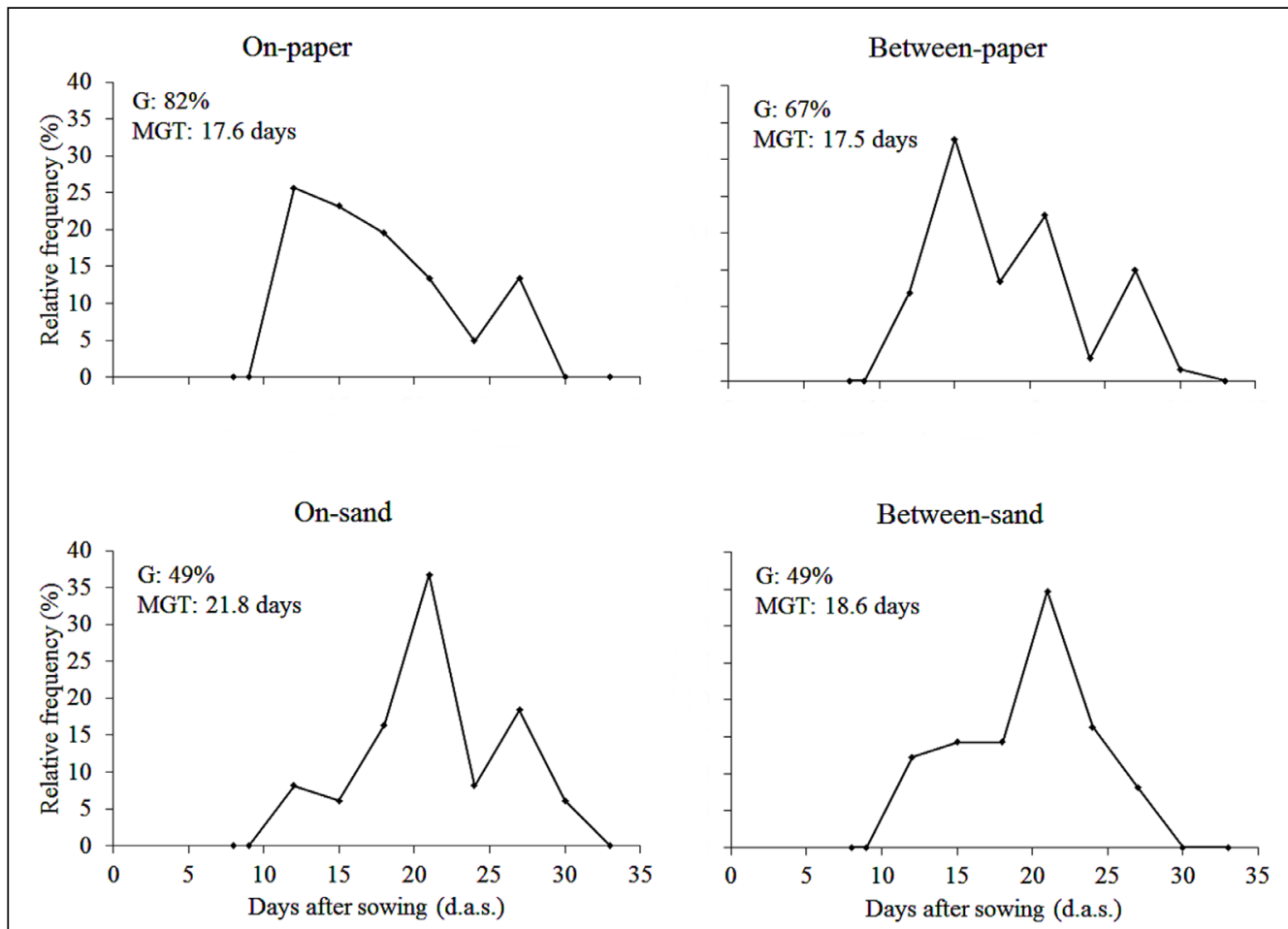

Paper roll

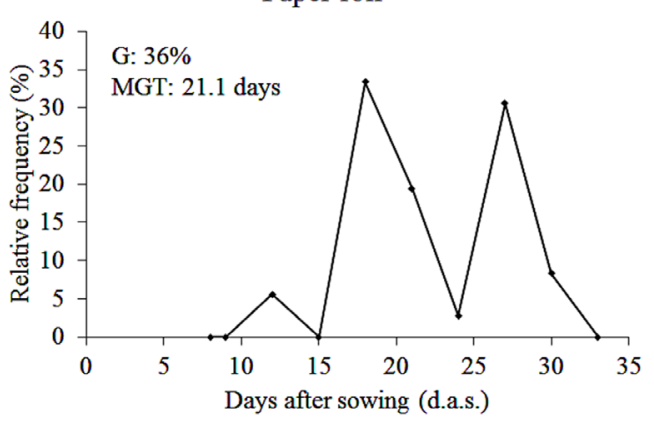

Figure 2 - Distribution of the relative frequency of emergence of Citrus limetta seedlings by seeds from different substrates $(\mathrm{G}=$ percentage of germination; $\mathrm{MGT}=$ mean germination time $)$.

occurs later, after 20 days, while for the others it was verified before.

Seedling emergence started around nine days after sowing, extending up to 30 days on paper and between sand, in the others it took additional time going up to 33 days. Similar periods have been reported by SOUZA et al. (2015) in evaluation of seed germination of citrus tangerine rootstock 'Sunki'.

For mean time, it was found that there was no difference between evaluated treatments, because in the frequency distributions they showed that mean time to emergence was 20 days (Table 1, Figure 2). There is no displacement of the polygon, as the mean times were similar, this implies that, even if not uniform, there was no displacement of polygonal line to the right or left of mean time, that is, there was no delay in seedling emergence process; fact also reported in studies of Spondias dulcis seeds (SOUZA et al., 2020).

\section{CONCLUSION}

Citrus limetta seeds are ovoid, slightly wrinkled and polyembryonic. Germination is hypogeal and may be cryptocotylar or phanerocotylar. 
Seedlings have leathery eophylls with simple leaves, elliptical shape or close to elliptical, tending to ovate. It has a pivoting root system that is colored yellow to cream with the presence of secondary roots.

The average germination time is between 18 and 22 days. The substrate indicated for seed germination is on paper.

\section{DECLARATION OF CONFLICT OF INTEREST}

The authors declare no conflict of interest. The founding sponsors had no role in the design of the study; in the collection, analyses, or interpretation of data; in the writing of the manuscript, and in the decision to publish the results.

\section{ACKNOWLEDGEMENTS}

The authors thank the Coordenação de Aperfeiçoamento de Pessoal de Nível Superior (CAPES), Brasil - Finance code 001 and Conselho Nacional de Desenvolvimento Científico e Tecnológico $(\mathrm{CNPq})$ for the financial support. There are no conflicts of interest.

\section{AUTHORS' CONTRIBUTIONS}

All authors contributed equally for the conception and writing of the manuscript. All authors critically revised the manuscript and approved of the final version.

\section{REFERENCES}

BHERING, L. L. RBio: A tool for biometric and statistical analysis using the R platform. Crop Breeding and Applied Biotechnology, v.17, p.187-190p, 2017. Available from: <https://www.scielo.br/j/ cbab/a/ndxxG8NyDnqfh9vDH48WTrK/?lang=en>. Accessed: Feb. 22, 2020. doi: 10.1590/1984-70332017v17n2s29.

BRASIL, Regras para análise de sementes. Brasília: MAPA/ DAS/ACS, 2009. 395p.

COELHO, R. I. et al. Caracterização morfológica da planta, frutos, sementes e plântulas de tangerina (Citrus reticulata L.) de ocorrência natural no sul do Estado do Espírito Santo. Revista Brasileira de Sementes (Atual Journal of Seed Science), v.23, p.294-301, 2001. Available from: <http://www.bibliotekevirtual. org/index.php/2013-02-07-03-02-35/2013-02-07-03-03-11/1009rbs/v23n02/11371-caracterizacao-morfologica-da-plantafrutos-sementes-e-plantulas-de-tangerina-citrus-reticulata1-de-ocorrencia-natural-no-sul-do-estado-do-espirito-santo. html>. Accessed: Feb. 22, 2020. doi: 10.17801/0101-3122/rbs. v23n2p294-301.

COLECIO-JUÁREZ, M. C. et al. Characterization of volatile compounds in the essential oil of sweet lime (Citrus limetta Risso). Chilean journal of Agricultural research, v.72, 275-280, 2012. Available from: <http://www.bioline.org.br/pdf?cj12043>. Accessed: Feb. 22, 2020.

DUARTE, F. E. V. O. et al. Poliembrionia e atributos morfológicos de sementes de porta-enxertos de citros. Revista Brasileira de Fruticultura, v.35, p.246-254, 2013. Available from: $<$ https://www.scielo.br/j/rbf/a/XF8yf9qFTtkCg4nr5xdCgGR/ abstract/?lang=pt $>$. Accessed: Feb. 22, 2020. doi: 10.1590/S010029452013000100028.

FERREIRA, D. N. S. et al. Sementes poliembriônicas de Carapa surinamensis (Meliaceae) tem vantagens para o desenvolvimento das plântulas? Acta Amazonica, v.49, p.97104, 2019. Available from: <https://www.scielo.br/j/aa/a/ Qxjs8BGXjxC8YkfWwwQgTys/?lang=en>. Accessed: Feb. 22, 2020. doi: 10.1590/1809-4392201801211.

GOMES, F. R. et al. Genetic Diversity and Characterization of Sweet Lemon (Citrus limetta) Fruits. Journal of Agricultural Science, v.12, n.8, p.181-190, 2020. Available from: <https:// www.ccsenet.org/journal/index.php/jas/article/view/0/43273>. Accessed: Feb. 22, 2020.

GUERRA, D. et al. Caracterização morfológica, determinação do número de embriões e taxa de poliembrionia em três porta-enxertos híbridos de citros. Bragantia, v.71, p.196-201, 2012. Available from: <https://www.scielo.br/j/brag/a/BqJwktQtBFzmCwDkZF5 $7 \mathrm{mhM} /$ ?lang=pt $>$. Accessed: Feb. 22, 2020. doi: 10.1590/S000687052012000200007 .

HASHEMI, S. M. B. et al. Fermented sweet lemon juice (Citrus limetta) using Lactobacillus plantarum LS5: Chemical composition, antioxidant and antibacterial activities. Journal of Functional Foods, v.38, p.409-414, 2017. Available from: <https://www. sciencedirect.com/science/article/abs/pii/S1756464617305625>. Accessed: Feb. 22, 2020. doi: 10.1016/j.jff.2017.09.040.

KASHYAP, K. et al. Study of polyembryony and development of molecular markers for identification of zygotic and nucellar seedlings in Khasi mandarin (Citrus reticulata Blanco). International Journal of Environment, Agriculture and Biotechnology, v.3, p.363-372, 2018. Available from: <https:// ijeab.com/detail/study-of-polyembryony-and-development-ofmolecular-markers-for-identification-of-zygotic-and-nucellarseedlings-in-khasi-mandarin-citrus-reticulata-blanco/>. Accessed: Feb. 22, 2020. doi: 10.22161/ijeab/3.2.8.

KONICA MINOLTA. Compreendendo o Espaço de Cor CIE $\mathbf{L} * \mathbf{C} * \mathbf{h}$. Available from: <http://sensing.konicaminolta.com. br/2015/08/compreendendo-o-espaco-de-cor-cie-lch>. Accessed: Feb. 22, 2020 .

MACHADO, C. G. et al. Adequacy of methodology for conducting germination test in forage pea seeds. Bioscience Journal, v.35, n.2, p.367-376, 2019. Available from: <http://www.seer.ufu.br/ index.php/biosciencejournal/article/view/41747>. Accessed: Feb. 22, 2020. doi: 10.14393/BJ-v35n2a20198-41747.

MAGUIRE, J. D. Speed of germination-aid in selection and evaluation for seedling emergence and vigor. Crop Science, v.2, p.176-177, 1962. Available from: < https://acsess. onlinelibrary.wiley.com/doi/abs/10.2135/cropsci1962.001118 3X000200020033x>. Accessed: Feb. 22, 2020. doi: 10.2135/ cropsci1962.0011183X000200020033x.

MAZZINI, R. B.; PIO, R. M. Caracterização morfológica de seis variedades cítricas com potencial ornamental. Revista Brasileira de Fruticultura, v.32, p.463-470, 2010. Available from: $<$ https://www.scielo.br/j/rbf/a/68kkJG7DKv8HPxhSRmvKxzR/ abstract/?lang=en>. Accessed: Feb. 22, 2020. doi: 10.1590/S010029452010005000043. 
MENDONÇA, A. V. R. et al. Morfologia de frutos e sementes e germinação de Poincianella pyramidalis (Tul.) L. P. Queiroz, comb. Nov. Ciência Florestal, v.26, p.375-387, 2016. Available from: $<$ https://periodicos.ufsm.br/cienciaflorestal/article/view/22738>. Accessed: Feb. 22, 2020. doi: 10.5902/1980509822738.

OUSSALAH, M. et al. Antimicrobial effects of selected plant essential oils on the growth of a Pseudomonas putida strain isolated from meat. Meat Science, v.73, p.236-244, 2006. Available from: $<$ https://pubmed.ncbi.nlm.nih.gov/22062294/>. Accessed: Feb. 22, 2020. doi: 10.1016/j.meatsci.2005.11.019.

SALIM, M. M. R. et al. Morphological characterization of tomato (Solanum lycopersicum L.) genotypes. Journal of the Saudi Society of Agricultural Sciences, v.19, n.3, p.233-240, 2020. Available from: $<$ https://www.sciencedirect.com/science/ article/pii/S1658077X18302728>. Accessed: Feb. 22, 2020. doi: 10.1016/j.jssas.2018.11.001.

SARMIENTO, A. I. P. et al. Morfologia de frutos e sementes de porta-enxertos de citros cultivados em ambiente protegido. Revista UDCA Actualidad \& Divulgación Científica, v.19, p.17-24, 2016. Available from: <https://www.lume.ufrgs.br/ handle/10183/206925>. Accessed: Feb. 22, 2020.

SANTANA, D. G.; RANAL, M. A. Análise da germinação: um enfoque estatístico. 1. ed. Brasília, DF: Editora Universidade de Brasília. 1962, 248p.

SHAKOOR, S.; NASAR, A. Removal of methylene blue dye from artificially contaminated water using citrus limetta peel waste as a very low cost adsorbent. Journal of the Taiwan Institute of Chemical Engineers, v.66, p.154-163, 2016. Available from: <https://www.sciencedirect.com/science/article/abs/pii/ S1876107016301742>. Accessed: Feb. 22, 2020. doi: 10.1016/j. jtice.2016.06.009.

SILVA, R. C. et al. Subsídios para propagação de espécie nativa do Brasil com potencial medicinal: Calophyllum brasiliense Cambess. Journal of Seed Science, v.41, p.318-327, 2019. Available from: $\quad<$ https://www.scielo.br/j/jss/a/nSy76RQHW9qJtjwt3SD DVsG/?lang=en>. Accessed: Feb. 22, 2020. doi: 10.1590/2317$1545 \mathrm{v} 41 \mathrm{n} 3214007$.

SOUZA, J. M. A. et al. Caracterização física e química dos frutos nos diferentes quadrantes da planta e germinação de sementes do portaenxerto cítrico tangerineira 'Sunki'. Bioscience Journal, v.31, p.425-432, 2015. Available from: <http://www.seer.ufu. br/index.php/biosciencejournal/article/view/22363/16117>. Accessed: Feb. 22, 2020. doi: 10.14393/BJ-v31n2a2015-22363.

SOUZA, P. H. M. et al. Dormancy overcoming in seeds of cajámanga (Spondias dulcis). Comunicata Scientiae, v.11, p.1-6, 2020. Available from: <https://www.comunicatascientiae.com. br/comunicata/article/view/3341>. Accessed: Feb. 22, 2020. doi: 10.14295/CS.v11i0.3341.

STRUIVING, T. B. et al. Physiological quality of seeds of citrus during cooling conditions storage. Ciência Rural, v.43, p.17771782, 2013. Available from: <https://www.scielo.br/j/cr/a/ qFrfhPf4hrRvmqnrpzGyXVH/abstract/?lang=pt $>$. Accessed: Feb. 22, 2020. doi: 10.1590/S0103-84782013001000008. 